\title{
THE STATUS OF MINORITY ETHNIC TEACHERS IN ENGLAND: INSTITUTIONAL RACISM IN THE STAFFROOM ${ }^{1}$
}

\author{
Linda M. Hargreaves ${ }^{2}$
}

\begin{abstract}
This paper reports research conducted with Black and Minority Ethnic (BME) teachers in England, specifically to find out (i) whether the status of teaching influenced their decisions to join the profession, and (ii) their perceptions of their status within the profession. The data are drawn from the national Teacher Status Project conducted in England 2002-6 combined with previously unpublished data from a follow up study with Asian teachers in 2007. The conclusions, based on focus groups with 65 teachers (African Caribbean, Pakistani, Indian, Bangladeshi) in four regions of England, are that the teachers were not influenced by the status of teaching but joined the profession for intrinsic reasons, such as to improve children's achievement, and to be role models for all children and for other teachers. Their self perceptions of their status within the profession are that it is low, as shown, for example, through the rejection of their culturally sensitive approaches to teaching, and their struggles to achieve leadership roles. The latter finding is repeatedly endorsed in studies of BME teachers and demands national monitoring of their career trajectories.
\end{abstract}

Keywords: occupational status: Black and Minority Ethnic teachers; Asian; African-Caribbean; role models; discrimination

Resumen: Este artículo presenta los resultados de una investigación llevada a cabo con profesores negros y de minorías étnicas en Inglaterra, específicamente (i) para verificar si el prestigio de la enseñanza había influido en su decisión de entrar en la profesión y (ii) para descubrir las autopercepciones de su estatus dentro de la profesión. Los datos fueron obtenidos a partir del Proyecto del Estatus del Profesor a nivel nacional, realizado en Inglaterra en 2002-2006, combinados con datos no publicados previamente de un estudio de seguimiento con profesores asiáticos en 2007. Las conclusiones, basadas en grupos de discusión con 65 profesores (afro-caribeños, pakistaníes, indios, de Bangladesh), residentes en cuatro regiones de Inglaterra, indican que a los profesores no les influyó el estatus de la enseñanza sino que habían entrado en la profesión por razones intrínsecas, tales como mejorar el rendimiento de los niños, y de ser modelos de conducta para todos los niños, además de para los demás profesores. Las autopercepciones de su prestigio en el ámbito de la profesión son bajas, como se ve, por ejemplo, en el rechazo de sus metodologías de enseñanza culturalmente sensibles y de sus luchas para alcanzar papeles de liderazgo. Este último hallazgo se avala repetidamente en estudios sobre profesores negros y de minorías étnicas y requiere la monitorización a nivel nacional de las trayectorias de sus carreras.

Hargreaves, L. M. (2011). The status of minority ethnic teachers in England: institutional racism in the staffroom. DEDICA. REVISTA DE EDUCAÇÃO E HUMANIDADES, 1 (2011) Março, 37-52 
Palabras clave: estatus ocupacional: profesores negros y de minorías étnicas; asiáticos; afro-caribeños; modelos de conducta; discriminación

\section{Introduction}

Since 1997, successive governments in England have been concerned to raise the status of teachers and the teaching profession. This includes the present Coalition government elected in May 2010. In October 2010, it published a paper entitled 'The Importance of Teaching', [Department for Education (DfE), 2010] which sets out its plans for education, and follows recognition that in the countries such as South Korea and Finland whose children outperform other countries in international achievement tests, teaching is a high status profession. In these countries, teachers' professional judgements are respected and headteachers have considerable autonomy in running the school. The government paper therefore states that:

In England, what is needed most of all is decisive action to free our teachers from constraint and improve their professional status and authority, raise the standards set by our curriculum and qualifications to match the best in the world (DfE, 2010: 8, par 5.).

The previous Labour government also aimed to raise the status of teachers and envisaged a position where, by 2012 ,

Our best teachers [will] have a status and role which makes them more like consultant doctors than either junior doctors or nurses, responsible for the most difficult teaching tasks, and also for the organisation of other teachers and teaching assistants (DfES, 2001: 18).

By 2006, however, as Everton et al. (2007) show, only 10 per cent of the public considered teachers similar in status to doctors, while the most common view, held by one in three respondents, was that teachers were of similar status to social workers or nurses. Teachers' pay is, of course, a definitive status issue, but by 2006, teachers' pay had become a top attractive feature of a teaching career.

In 2002-6, the Teacher Status Project (TSP) investigated the status of the teachers and teaching in England. The research included very large scale national surveys of public opinion and of teachers' perceptions of their status in 2003 and 2006, and an extensive programme of case studies in 2004-5 (Hargreaves et al., $2007 a ; 2007 b)$. The TSP is, to date, the most comprehensive study of teacher status in England. A key strand of the research focused on BME teachers' perceptions of their status within the profession

The status of minority ethnic teachers in England... 
(see Cunningham, 2006; Cunningham; Hargreaves, 2007; Hargreaves et al., 2007b). The present paper reiterates some of those findings but incorporates new data from a follow-up study with Pakistani, Bangladeshi and Indian teachers. The paper will argue that while the status, or prestige, of teaching did not deter these teachers from entering the profession, their treatment within the profession, and in particular the barriers they have faced in relation to promotion to senior leadership roles suggests a high degree of institutional racism within the teaching profession in England. After brief sections on the concept of status and the status of teachers in England, to provide necessary context, we present examples of evidence to illustrate this argument.

\section{What do we mean by the status of teachers?}

Attempts to define social status have occupied sociologists for decades and space precludes detailed discussion here. Turner (1988) usefully traces the developing complexity of the status construct with a series of definitions that take into account Marxist, Weberian and ultimately Bourdieuan (Bourdieu, 1984) analyses in which concept of 'cultural capital', and the significance of the lifestyle choices that indicate individual self-identities as expressions of status. Turner eventually defines status as:

... a bundle of socio-political claims against society which gives an individual (or more sociologically a group) certain benefits and privileges, marking him or her off from other individuals or groups. ... This cultural aspect of status gives rise to a second dimension, namely the notion of status as a cultural lifestyle which distinguishes a status group with a special identity in society (Turner, 1988:11).

At its simplest, status can be understood in terms of two dimensions: (i) status ascribed by birth, (e.g. age, gender) versus status achieved by personal effort, and (ii) objective status, determined by external recognition and reward, versus subjective or personal sense of status.

Along these dimensions English teachers tend to come from relatively low socio-economic status backgrounds (low ascribed status) but acquire high achieved status through their qualifications and training. Their objective status, that is the pay and conditions society awards them tend to be low. Their subjective sense of status then will depend on the relative importance of material rewards such as pay versus the intrinsic satisfactions, or what Lortie (1975) called 
the psychic rewards of their work in helping children and seeing them succeed.

Hoyle (2001) analyses the occupational status of teaching in England, and identifies this concern for children, along with a lack of specialised exclusive expertise, and low pay, for example, as one of the barriers to improving the occupational prestige of teaching.

For BME teachers in England, qualification as a teacher may still be an upwards step from low ascribed status to higher achieved status. It brings membership of a status group of higher occupational prestige (see Ganzeboom; Treiman, 1996) than many occupations commonly available to minority ethnic communities (e.g. bus and taxi drivers, cleaners, waiters, shopkeepers) (Green; Owen; Wilson, 2005).

\section{The status of teaching in England}

Two key findings from the Teacher Status Project are presented here. First, teachers in England perceived a dramatic decline in their status since the 1960s when they had enjoyed considerable professional autonomy (Figure 1). From 1979 onwards the governments led by Margaret Thatcher, and later Tony Blair gradually removed that autonomy. Their policies told teachers what to teach through a compulsory National Curriculum, how to teach it through prescriptive frameworks for teaching literacy and numeracy and introduced high stakes national assessments, a fierce Inspection system, and a market economy in which schools must compete for pupils. While policymakers saw these reforms as professionalising the 'workforce', many teachers felt themselves de-professionalised (Alexander, 2004, 2010; Galton \& MacBeath, 2008), and this is reflected in Figure 1 (Hargreaves et al., 2007b).

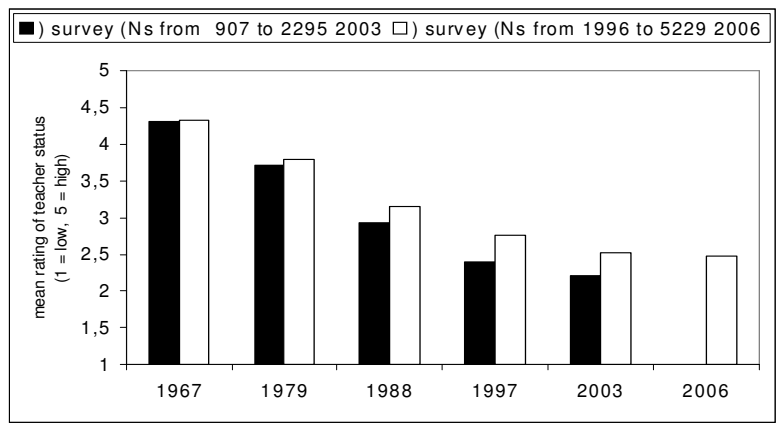

Source; Hargreaves et al., 2007b

Figure 1: Teachers' perceptions of their declining social status 1967-2006

The status of minority ethnic teachers in England... 
Secondly, we asked over 2000 teachers in 2003, and over 5000 in 2006, to say how far 19 characteristics of a 'high status profession' were true of the teaching profession. They saw a high status profession as characterised by reward and respect, with some control and regulation. For the teaching profession these perceptions were reversed: teaching was characterised by control and regulation, with significantly less reward and respect. By 2006 perceptions of teaching had moved very slightly closer to those of a high status profession, but it would take until 2024 at that rate of change, for the gap to close. As noted at the beginning, the present government plans to relax the control and regulation placed on teaching, and has promised greater freedoms and more money for schools. The effect on teachers' status remains to be seen. Having considered the status of teachers generally, the remainder of the paper will focus on the status of black and minority ethnic teachers in England.

\section{The status of black and minority ethnic teachers in England}

\section{National Statistics of teacher ethnicity}

In England nationally there has been a concern since the early 2000s to increase the participation of people from minority ethnic backgrounds in the teaching profession. National statistics, however, reveal just a 1.3 per cent increase in BME teachers since 2004. Figures for 2010 show 94.0 per cent white teachers in total (White British $88.9 \%$, White Irish $1.4 \%$, other White, $3.7 \%$ ), of the 94.8 percent who provided information (ONS, 2010). This average figure masks a very uneven regional distribution of BME teachers. In eight of the nine regions of England, under 10 per cent of the teachers are of black or minority ethnic heritage and in the North east the figure is 1 per cent. In Inner London, however, 41.5 per cent are of minority ethnicity, and 11.3 per cent describe themselves as Black or Black British (ONS, 2010). Since just under one in four of our pupils belong to BME groups (National Archives, 2009), the limited diversity in the teacher population outside London is problematic.

Several surveys of Black and minority ethnic teachers' attitudes, concerns and experiences as teachers have been conducted in recent decades in England, while the meta-analysis by Quiocho \& Rios (2000) of research in the US and elsewhere between 1989 and 1998 reveals the seriousness and breadth of concerns. Among the British studies, similar issues have been 
identified repeatedly over a period of 15 years. Ranger (1988) reported a Commission for Racial Equality survey of 1983-4 which showed that minority ethnic teachers were few in number, overrepresented on low salary scales, and typically employed in shortage subject areas, or where the needs of minority ethnic pupils were involved. Ross (2002) and The Runnymede Trust (2003) identified similar concerns to those listed above, namely subject stereotyping, restricted promotion opportunities, and the expectation that they would 'deal' with issues concerning minority ethnic pupils and their parents, or other issues of discrimination or racism.

Maylor, Dalgetty and Ross (2003) using the General Teaching Council's 2002-3 annual survey data, confirmed the uneven distribution of BME teachers across the country. They found also that while BME teachers' views were the same as those of white teachers in most areas, they were more likely to be motivated to become teachers by a desire to give something back to the community, to want to stay in the profession, but were more concerned that their opportunities for professional development were fewer than those of their white colleagues. Such themes also recur with depressing regularity. Finally, Ross (2002: 10) cites research which suggests that teaching was not seen as a sufficiently prestigious profession by Asian participants, particularly for Asian men.

Given this background, this paper will pursue two research questions posed by the Teacher Status project, namely:

- What part does the current status of the teaching profession play in attracting people from minority ethnic backgrounds to the profession?

- What is the status of teachers from minority ethnic groups within the profession?

\section{Methodology}

The data were collected in two stages through as series of focus group interviews with teachers in nine local authorities in the North-West, West Midlands, East Midlands and London where the highest proportions of minority ethnic teachers were located. In the first study, 33 African Caribbean teachers took part but a whole group of Asian teachers withdrew, concerned that their participation might have poor consequences for their career prospects. We therefore carried out a continuation study in early 2007, involving Bangladeshi, Pakistani and Indian teachers. In total then 33 Black 
African-Caribbean teachers and 32 Asian (Pakistani, Bangladeshi and Indian) teachers took part. The group interviews were recorded, transcribed and coded manually to identify the principal themes emerging from the different groups by ethnicity and region.

\section{Findings}

Our first research question asks, 'What part does the current status of the teaching profession play in attracting people from minority ethnic backgrounds to the profession?' In Hoyle's (2001) terms, this examines the teachers' perceptions of the occupational prestige of teaching, and how this affected their decisions to join the profession. For the majority of the teachers, the prestige of the profession was of no consequence, although some referred to their parents' misgivings. Just as with the teachers reported in the main TSP, the motivation to teach had often been a life long ambition:

I've always wanted to do it, since I was seven years old and I just followed my dream. (African Caribbean deputy head teacher)

It was a sort of family tradition but because it was such high status in our house (both parents were teachers) it was something you aspired to rather than looked down on' (Bangladeshi chemistry teacher, Lancashire)

My parents wanted the stereotypical doctor, dentist, and I grew up with that idea ... [but on not achieving high enough examination results, decided on teaching] In those days parents had a big influence and they said' if you are going to teach, then it's secondary., so I went into secondary science teaching ... (Indian LEA Ethnic Minorities support teacher, Leicester)

For several, a vivid experience of being taught by a black teacher ultimately inspired them to teach.

... in 1961, we had an exchange of teachers at my primary school, and the American teacher that come over was black and I was so shocked, I ran home and told my dad we had a teacher and she was black. As a child I was relieved to see that you could have teachers who are black or mixed heritage. It's so important. Now I'm quietly saying to kids 'You could do it'. (African Caribbean teacher, North West) 
As one teacher pointed out realistically, 'one of the reasons why [teaching] may not be promoted in ethnic minority homes this might be to do with the salary you get'. Teachers' salaries, as it was pointed out, were 'not anywhere near' those of doctors and lawyers'. Another noted that, 'It's not a glamorized profession and you don't see positive programmes on television which encourage the population to think 'yes, I want to be a teacher'. While the status of teaching had not deterred these people, they acknowledged that it might deter others:

The notion that in some communities that everyone wants to become doctors or lawyers, and it was like that in our community as well. I think that's the stereotype, maybe not so much now but definitely it was before. I think that's one of the reasons why people don't go into teaching. (Male Bangladeshi secondary ICT teacher, Lancashire)

Overwhelmingly more important than the status of teaching, however, regardless of ethnicity, were intrinsic reasons for wanting to teach, principally:

- their own altruistic motivation to act as role models for all children,

- to improve educational opportunities for children,

- and to influence what they perceived as a mono-cultural system which fails to recognise or acknowledge the histories and identities of minority ethnic children.

Indian teachers were less likely to say they wished to be role models, and several of them had come into teaching as a second career. However, while one Bangladeshi teacher in London noted that '... some Bangladeshi teachers believe that they should not be expected to be role models ... [but] I think role models are important', the majority of the teachers expressed the importance of having BME role models - but, critically, not solely for the benefit of minority ethnic children, but for all children, and for other teachers:

... there needs to be a role model for black students ... but I also think it is important too for the white children to see black teachers... (headteacher, West Midlands)

... That's why I came it teaching. I wanted there to be more Black role models in schools. I wanted [minority ethnic pupils] to think 'I can do whatever I want, it doesn't matter what colour I am'. 
(Advanced Skills Teacher, London)

It's important, not just for children ... but for other staff in the school to see staff from minority ethnic backgrounds - especial so for leadership positions ... if you're a minority ethnic teacher you've got a dual role to play: you've got to be a role model for the children, you've got to be a role model for the community [the school] serves and, you're like a role model for the staff in the school. (female Pakistani school improvement consultant, North West)

In the face of reports showing that attainment grades for Indian and Chinese pupils exceeded those for all other groups, while African Caribbean, Bangladeshi and Pakistani pupils' grades were worse than those of White pupils in all age groups (Bhattacharyya et al., 2003), there was a strong sense of the need to tackle decades of underachievement, both through being role models and tackling the problem of curriculum content. As one West Midlands African Caribbean teacher put it, that, 'The national curriculum is all about keeping Britain white. Yes you live here but you're not really part of the system as such'. There was a strong shared concern that the National Curriculum largely omits history, literature etc relevant to England's BME people.

[Government] have got alarming statistics talking about 28 per cent of Black kids have got SEN statements. And some other frightening facts which I just think are completely untrue. There are not enough people like us to deal with them. We just don't have enough role models - there's nothing wrong with the kids'. (Teacher, West Midlands)

I came into teaching 14 years ago, and it was about the lack of Black history in the curriculum, but I was fortunate - I had three black teachers when I was at school (African Caribbean Assistant Head and SENCO, North West)

If you look at a good quality teacher he or she with enough breadth would be saying, 'I'm going to deliver this subject. I'll look at the make up of the school but at the same time I want to look at the material that is available because we are talking about a multi-racial society. I want to make sure that I'm reflecting everybody's culture within my lessons and within my curriculum and within my school.' (African Caribbean, assistant headteacher, West Midlands) 
One recent development in English schools has been a rise in the employment of Teaching Assistants (TAs) to free teachers from routine tasks (such as photocopying, collecting money) and allow teachers time to plan together. One Indian secondary teacher referred to this:

I think that it's sometimes [important] for children to see Asian teachers or Asian headteachers because a lot of the support staff are usually ethnic minority, so it would give the child an aspiration of where they could go. (Male, Physical Education teacher, Leicester)

Many teachers felt that seeing minority ethnic teachers in senior and headteacher roles would have a greater impact on the aspirations of youngsters, while the dearth of minority ethnic people in policy-making positions in local and central government was also deplored:

We need more at the top of the ladder because that's where you are going to make the impact. Not only as a headteacher you need to start going to the [town] Council because even if you are a headteacher you are curtailed by them [local councilors]. (African Caribbean Deputy headteachers, London)

I suppose from the minority ethnic backgrounds the person with the highest position would be myself within the LEA, and we're still not anywhere near the top ... in the higher tier there isn't anyone from a minority ethnic background. We've got a few deputy heads from ME background - you could count them on one hand - and we've no heads from Pakistani or Bangladeshi heritage. (Pakistani, School Improvement Consultant, North West)

This situation reflects the difficulties many minority ethnic teachers have faced in seeking promotion, and leads into our second research question: What is Black and minority ethnic teachers' sense of status within the profession?

At the initial stage I think there is positive encouragement but the difficulty arises further up the ladder when you are challenging the host community. That's where the negativity of the glass ceiling hits you ... when you see others go past you in the race and you're 
left behind, and you're putting in your full shilling but why is it you are getting so little change? (Pakistani, female secondary science teacher, Lancashire)

In Hoyle's (2001) terms this is probably closest to perceived occupational esteem that is the recognition by others of the care, competence and conscientiousness that teachers bring to their work. In our main study we found that the esteem teachers perceived from colleagues, pupils and often parents insulated them from prestigedepressing government policies, and what they perceived, validly in the 1990s but not in the 2000s, to be a negative media portrayal of teaching (Hansen, 2009; Hargreaves et al., 2007a). While some of the BME teachers also enjoyed positive indicators of esteem from pupils, parents and sometimes from external agencies such as school inspectors, many of them expressed strong perceptions of negative esteem and racial discrimination from several sources. These included not only white working class parents but also minority ethnic parents:

The school I work at now is $100 \%$ Asian... when I first started I was the first Asian teacher to work there ... and you wouldn't think, the school being in th[at] community, the stereotypes they (pupils) were bringing into the classroom. Even this year I had someone's dad saying he'd rather have a white teacher teach his child ... I didn't think it would be, but it's as challenging as an all white school. (Bangladeshi woman secondary science teacher)

She went on to point out that the parents themselves 'have hardly any positive experiences of school so they don't view school in a positive way'. On the other hand, a Bangladeshi secondary ICT teacher from the same area told us that his present school allowed him time to go and pray at the mosque. This had been his condition of employment and the school, unusually, understood and accepted it.

Stories of the struggle to gain promotion were common not only to senior positions, but also in promotions that recognised their pedagogic and academic ambitions as opposed to their pastoral skills. The African Caribbean teacher quoted below told us how she had become aware of this after she was promoted following an OfSTED inspection: 
I don't think that heads will do anything unless they have to. ... they're quite happy with the status quo, they will keep black people where they are ... because in primary there are lots of women ... not really believing that they need to get anything more from it ... happy with the amount of money they are getting and happy that they are doing a good job. ... Even though the head eventually promoted me, she only promoted me after [the Inspectors] came and gave me the highest ratings of all the teachers. I got excellents and very goods through out my teaching. (African Caribbean teacher, North West)

Thus, the attitudes of headteachers were seen as critical in this process while there was concern that BME teachers themselves needed to be more ambitious. The link between these two positions, of course, is the need for more BME headteachers as role models for the teachers.

For my head of department post I had to apply for jobs at various places. It took me five years and in the end I believe the single factor that got me this post was the fact that the head was an African Caribbean and she gave me the opportunity. (African Caribbean, male, Head of Department, West Midlands)

The teachers were unanimously opposed to positive discrimination, however, placing emphasis on the quality of teaching regardless of ethnicity, but there was agreement that more careful monitoring of BME teachers' careers was desirable. Although there were positive stories, they were as Ajegbo et al. (2006) also acknowledged, 'far from the norm', and often located in specific geographic locations:

In Oldham, there's a change for previous years. If there's a teacher from a minority ethnic background, schools will try to employ them especially if they know the teacher is a good teacher and meets all the criteria - there's more impetus [now] to employ them. (Pakistani, school improvement consultant, North West)

No problem. Maybe because it's Leicester. Leicester is more equal opportunities [aware]. (Indian teacher)

... senior management are very encouraging and I managed

The status of minority ethnic teachers in England... 
to secure a management position this year. ... Our headteacher explained that ... a lot of kids parents are active members of the [racist] British National Party. ... what they're doing at our school is to put in a lot of teachers from minority backgrounds ... [and] main minority ethnic teachers presence felt in the staffroom - but our headteacher's agenda might be different from other schools'. (Bangladeshi male secondary head of department, North West)

Of course, the 65 minority ethnic teachers who talked to us might simply have had personal grievances which they attributed to racial discrimination, but our sample included people in senior posts and local authority positions that have high occupational prestige, who had also experienced difficulties on the way. Nevertheless the continued existence of these negative experiences, and more extreme ones are reported by Hargreaves et al. (2007b) is a serious indictment of our education system. Along with Ross (2002) and McNamara et al.'s (2009) recent study of BME leadership aspirations, our findings are strongly suggestive of ingrained institutional racism in the teaching profession.

Space precludes discussion of other themes that emerged from our study, such as the lack of respect for BME teachers' specific pedagogical expertise, or that their career options are severely limited by a continued sense that large areas of Britain are effectively geographical exclusion zones, that they are reluctant to apply for jobs for fear of racial abuse. Both themes are indicative of institutional racism and are detailed by Cunningham and Hargreaves (2007) and Hargreaves et al. (2007b).

\section{Conclusion}

The Teacher Status Project found that neither teachers nor the public consider teaching to be a high status profession, although pay was no longer the main issue. Teaching's status was perceived to have declined dramatically since 1967, and although showing small signs of recovery, it will take until 2024 at that rate of change for teaching to be perceived as a high status profession.

BME teachers just like their white counterparts, were not deterred from joining the profession by its status, however. Their motivation to teach was more often a long-term ambition, sometimes inspired by a black teacher or headteacher. There was a common view that it was important to be a role model, not only as teacher but as a headteacher, to inspire not only children, but also BME and 
white teachers. The title of this paper refers to institutional racism in the staffroom in relation to BME teachers' attempts to gain promotion to leadership roles. The teachers went beyond this, to highlight the glaring absence of BME people in senior policy-making positions in local and central government and the limitations that this places on the potential for change. The prevalence of the teachers' stories, too many to present here, from north west to south east in our study, of their struggles to achieve promotion to senior posts, and the roles they are assigned, are indicative of an endemic institutional racism in our education system. Similar evidence and consistent concerns arising from research in this field over the last 20 years, have been endorsed by McNamara et al.'s (2009) study of BME teachers' careers, and validate this view. How long will it take to achieve a system that accords all teachers the status they deserve, and a level of diversity in the teaching profession that would not only improve the achievement of BME pupils, but also stop the waste of talent among BME teachers?

\section{References}

Ajegbo, K.; Kiwan, D.; Sharma, S. (2006). Curriculum Review: Diversity and citizenship. Nottingham: DfES. Accessed 25/1/07. Available at: http://publications.teachernet.gov.uk/eOrderingDownload/DfES_Diversity\&Ci tizenship_doc.pdf

Alexander, R. J. (2004). Still no pedagogy? Principle, pragmatism and compliance in primary education. Cambridge Journal of Education, 34, 1 (2004) 7-33.

Alexander, R. J. (2010). Children, their world, their education. Final report and recommendations of the Cambridge Primary Review. London: Routledge.

Baker, M. (2010). What does academy status really mean? Accessed 29/1/11. Available at:

http://www.mikebakereducation.co.uk/articles/70/what-does-academy-statusreally-mean

Bhattacharyya, G.; Ison, L.; Blair, M. (2003). Minority Ethnic Attainment and Participation in Education and Training: The evidence. RTP01-03. London: DfES.

Bourdieu, P. (1984). Distinction: A social critique of the judgement of taste. London: Routledge and Kegan Paul.

Department for Education (DfE) (2010). The importance of teaching. The Schools White Paper. Cm 7980. Norwich: The Stationery Office.

DfES (Department for Education and Skills) (2001). Professionalism and Trust: The future of the teaching profession. Secretary of State's Speech to the Social market Foundation. November 2001. London: DfES. 
Cunningham, M. (2006). Minority ethnic teachers as socio-cultural empathisers: Findings from the Teacher Status Project. International Journal of Learning, 13, 6 (2006) 79-86.

Cunningham, M.; Hargreaves, L. (2007). Minority ethnic teachers' professional experiences. Research Report RR853. London: DfES. Available at: http://www.educ.cam.ac.uk/research/projects/teacherstatus/

Everton, T.; Turner, P.; Hargreaves, L.; Pell, T. (2007). Public perceptions of the teaching profession. Research Papers in Education, 22, 3 (2007) 247-265.

Galton, M.; MacBeath, J. (2008). Teachers under pressure. London: National Union of Teachers/ Sage.

Ganzeboom, H. B. G.; Treiman, D. J. (1996). Internationally comparable measures of occupational status for the 1988 International Standard Classification of Occupations. Social Science Research, 25 (1996) 201-239.

Green, A.; Owen, D.; Wilson, R. (2006). Changing patterns of employment by ethnic group and for migrant workers. National Report. Warwick Institute for Employment Research. Coventry: Learning Skills Council. Accessed 30/1/11. Available at:

http://readingroom.Isc.gov.uk/lsc/2006/research/commissioned/natchangingpatternsofemploymentbyethnicgroupandformigrantworkers-remay2006.pdf

Hansen, A. (2009). Researching 'teachers in the news': The portrayal of teachers in the British national and regional press. Education 313, 37, 4 (2009) 335-347.

Hargreaves, L.; Cunningham, M.; Hansen, A.; McIntyre, D.; Oliver, C. (2007a). The status of teachers and the teaching profession in England: views from inside and outside the profession - Synthesis for the final report of the Teacher Status Project. RR831A. London: DfES. Available at: http://www.education.gov.uk/rsgateway/DB/RRP/u013771/index.shtml

Hargreaves, L.; Cunningham, M.; Everton, T.; Hansen, A.; Hopper, B.; Mclntyre, D.; Oliver, C.; Pell, T.; Rouse, M.; Turner, P. (2007b). The status of teachers and the teaching profession in England: views from inside and outside the profession - Evidence Base for the Teacher Status Project. RR831B. London: DfES. Available at:

http://www.educ.cam.ac.uk/research/projects/teacherstatus/

Hoyle, E. (2001). 'Teaching prestige, status and esteem'. Educational Management and Administration, 29, 2 (2001) 139 -152.

Chicago Press

Lortie, Dan C. (1975). Schoolteacher. Chicago: University of

McNamara, O.; Howson, J.; Gunter, H.; Fryers, A. (2009). The leadership aspirations and careers of black and minority ethnic teachers. Report for NASUWT and National College for Leadership of Schools and Children's Services. Accessed 10/8/10. Available at:

http://www.nationalcollege.org.uk/index/docinfo.htm?id=31703

The status of minority ethnic teachers in England... 
Maylor, U.; Dalgety, J.; Ross, A. (2003). Minority Ethnic Teachers in England. London: GTC.

ONS (Office for National Statistics) (2010). Statistical First Release School workforce in England January 2010 (Provisional) SFR11/2010. London: Department for Education. Accessed 30/1/11. Available at: http://www.education.gov.uk/rsgateway/DB/SFR/s000927/sfr11-2010v2.pdf

National Archives (2009) Statistical First Release: School, pupils and their characteristics January 2009 (Provisional) (SFR 08/2009). Accessed 30/1/11. Available at:

http://webarchive.nationalarchives.gov.uk/20100217093418/http://dcsf.gov.u k/rsgateway/DB/SFR/s000843/SFR08_2009.pdf

Quiocho A.; Rios, F. (2000). The power of their presence: minority group teachers and schooling. Review of Educational Research, 70, 4 (2000) 485-528.

Ranger, C. (1988). Ethnic Minority School Teachers: A survey in eight local education authorities. London: Commission for Racial Equality.

Ross, A. (2002). Institutional Racism: the experience of teachers in schools. Paper presented at the British Educational Research Association Annual Conference, Exeter, September. Accessed 30/1/11. Available at: http://www.dorsetrec.org.uk/Pubs/Reports/Docs/racism\%20BERA\%202002. PDF

Runnymede Trust (2003). Black and minority ethnic issues in teaching and learning. Briefing paper. Accessed 25/1/07. Available at: http://www.runnymedettrust.org/projects/education/BMEissuesDiscussionPa per.pdf Press.

Turner, Bryan S. (1988). Status. Milton Keynes: Open University

\footnotetext{
${ }^{1}$ El estatus de los profesores de minorías étnicas en Inglaterra: el racismo institucionalizado en la sala de profesores

${ }^{2} \mathrm{PhD}$.

University of Cambridge (United Kingdom).

Email: Ih258@cam.ac.uk
} 